\title{
Ontologies in the problems of building a concept domain model
}

\author{
G.P. Vinogradov 1, Dr.Sc. (Engineering), Professor, wgp272ng@mail.ru \\ A.A. Prokhorov 2, Branch Manager, forworkap@mail.ru \\ 1 Tver State Technical University, Tver, 170026, Russian Federation \\ ${ }^{2} R \& D$ Institute Centerprogramsystem, Tver, 170024, Russian Federation
}

\begin{abstract}
The purpose of the research is the problem of communication between information systems and between an information system and an operator. The problem is relevant due to the IT intellectualization that leads to the fact that an information system acquires the features of an intellectual agent. So, there are new prospects for the digital economy, where information interaction at the network level plays an important role.

The methodological basis of the research are the results from theoretical semiotics, from the use of ontology as a form of real world knowledge representation, as well as the publication of domestic and foreign scientists on the problem of communication between information systems.

The research includes the communication process analysis. It is revealed that the intelligent agent considers a message as a decision result either to inform or to change the status of another agent. It is shown that communication should be considered as one of the types of control, such as behavior.

The authors prove that, in relation to the theory of behavior, this approach requires including psychological aspects into the subject area of the theory of choice. First of all, these are the problems of perception, awareness, understanding the properties of the situation of choice and building assessments of the results of choice, communication, conflict, the introduction of new concepts and the relations between them of a number of others. Communication process support systems should contain a domain model that is understandable and interpreted by a user. It is shown that conceptual modeling of the subject domain based on ontologies is the most appropriate way to build it. The conceptual model consists of a conceptual structure and a concept content description. A conceptual structure is a set of concepts on which four abstraction maps are defined: generalization, type designs, association, and aggregation. A concept content description is carried out using database tables. The essential difference of the used conceptual model from others is describing an association as a usual concept. It is shown that, due to the semantic invariance of conceptual interpretation, it is possible to improve technological and operational characteristics of an information system.

The proposed approach creates the basis for the development and organization of the interface of artificial entities both among themselves and with an operator based on a certain "professional language", which is relevant to a particular subject domain. This involves considering an interface as a sign system and using methods of the theory of artificial intelligence to build it.
\end{abstract}

Keywords: decision making, purposeful systems, fuzzy judgment, choice situation

Nowadays, the transition to the knowledge economy causes the tendency to intellectualize information systems and the maximum possible automation of business processes. This raises a number of problems of organizing the interaction of such systems between themselves and operators. The point is that the information system acquires the features of an intellectual agent, so there are new opportunities for the direction called "information technologies".

In practical programming, an agent is a computergenerated system that is located in some environment. It is designed for autonomous actions in this environment in order to achieve specified goals. There are some known limitations preventing the widespread use of MAC technologies that use the BDI architecture of an agent. The desire to bring the concept of building agents in accordance with modern requirements is currently associated with using biological principles and searching for analogs in wildlife and human society. Thus, the papers [1-4] identify and describe components and observed parameters of purposeful behavior using the formalism of fuzzy systems. In [5-10], the authors consider the problem of a subjective rational choice related to satisfaction of needs, execution of ob- ligations and the system of values and norms. Such form of choice makes individual purposeful behavior possible. In addition, it makes it possible to describe behavior as a process. Observation over it allows identifying individual steps - subprocesses; their interaction combination forms a system.

An important subprocess in such system is formation of vision of the situation of choice. They should be considered as models. Their description form can be different: textual, mathematical, verbal, etc. [8]. They are the basis for the forecast of possible states from the selected modes of action, as well as for estimating the probability of their obtaining and the degree of desirability [10]. We propose to consider the theory of ontologies as a way to build representations. Many representations form a knowledge base, which is adapted due to the communication between information systems and the external environment.

\section{The communication problem in information systems}

Formation of a vision is based on the processes of obtaining information from the environment. The main 
channels are: communication with other subjects, internal dialogue, observation.

Three main processes - perception, awareness and experience - together give the concept of a situation, generate new concepts, change and supplement the list of beliefs (knowledge base). This is the basis for forming a model (vision) of the situation of choice. The driving factor of behavior is affective evaluation of the realization of needs and capabilities. Assessments of the current situation cause a state of satisfaction/dissatisfaction in a subject, who characterizes them by feelings and attitudes. The agent selects from the known set of methods and opportunities those that allow him to reach the state of satisfaction rationally.

The model of agent's subjectively rational choice of ways to meet the needs and fulfill obligations is based on the methodology of gradual strengthening of agents' capabilities. The latter assumes that in the process of searching for ways to meet the needs, the agent gradually builds up a variety of ways do this. Here he uses his experience and experience of other agents he interacts with, as well as the available knowledge.

In most models of agents, their behavior is described by sociological and psychological concepts; communication is defined in terms of protocols that do not have a direct connection with the first ones. Due to such approach, one of the problems is in complicated developing and modeling communication between agents, as well as operators with agents. This is due to the fact that the description of agents' autonomous behavior contains high-level abstractness formalism, communication is defined in terms close to implementation. The difference in description levels does not allow simulating communication between agents at the same level as their autonomous behavior is described.

In existing information systems (which include software agents), communication is based on the socalled command interface. It is implemented through dialog boxes, menu systems, etc. When artificial entities communicate, the main problem is creation of message formats and ways of organizing information channels.

Complication of solved problems leads to the necessity of organizing an interface by artificial entities between themselves and an operator based on some "professional language" that is relevant to some subject area. This involves considering an interface as a sign system.

\section{Ontologies and building an interface between information systems and an operator}

Let an interface language phrase describes some situation $S$, which has a meaning and a name. This phrase might have the mode of action $A$ from a set of possible ones. Its implementation puts the environment into a new state. It is clear that a correct interpretation of environment perception results will lead to a correct choice of a mode of action. This means that the choice $A$ in the perception $S$ should suppose the existence of the vision that act as a domain model that indicates the fact that the agent understands the relationships between stimuli and system reactions. A set of such models forms a knowledge base.

The creation of such knowledge base involves development and integration of conceptual models of subject areas into its information systems. The main purpose of conceptual modeling is the formalization of accumulated knowledge about a certain subject domain in the form closest to understanding by participants in the communication process. In practical terms, the most promising direction of conceptual modeling is ontological modeling. Ontologies are explicit formal specifications of domain terms and relationships between them. This social science term is used in the theory of agents. It is almost equivalent to the concept of language semantics in a certain subject domain common in programming.

The ontology rules specify statements that relate concepts and relationships between them. However, these models have a number of limitations. For example, the relationship between concepts may be concepts themselves. Overcoming this shortcoming is associated with using conceptual modeling of a subject domain.

The approach supposes that association is also a concept rather than a named type of connection, which sets a role or relation in a model. In addition, the language of the conceptual model does not contain means for describing relations and roles, since the conceptual structure contains all the rules necessary for derivation.

This allows increasing the level of model abstraction and developing a small number of general algorithms with a small computational complexity that do not depend on the subject domain, since they are formulated in the most general operations on concepts.

There are four types of concepts: single, simple, specific and abstract $[11,12]$.

Single concepts are the result of a mental selection of unique entities in a subject domain and assigning names to them. This allows replacing the entity with a sign that is identical to it in some sense. Simple concepts are formed by combining entities similar in some sense. They are assigned a unique name, considered as a single concept, and acceptable manifestations (values) range is defined, considered as a set of single concepts. Specific concepts are based on a union of entities with the same characteristics, which allows defining a set of entities that correspond to a notion. The features to be distinguished are considered as simple concepts, and the names of concepts are considered as single concepts. A particular concept is represented by a set of entities that form its extensional or volume. The name of a concept is a sign expression of a concept with an 
attributed meaning. The scheme or structure of the concept is set by a set of characteristics that characterize the concept. The intentional or content of the concept is considered as a set of values of interrelated characteristics that allow recognizing the entities belonging to the concept. At the same time, entities should be considered as some fragments of a subject domain represented by signs, symbols, images, etc. In order to manipulate entities in an information system, they must be called and treated as single concepts.

Formation (determination) of abstract concepts includes using complex forms of abstraction based on the establishment of relations of independence, differentiation and integration of features between the concepts. To form abstract concepts, there four abstractions: generalization-specialization, typing-concretization, aggregation-decomposition, and association-individualization.

The process of studying a subject domain supposes formation of new concepts or identification of existing ones. In this case, from the perspective of solving a certain problem, there are entities that have or are assigned with certain names. Further, the set of identified entities is analyzed in order to define their similarities and differences. Similar entities are grouped and form concepts or fill existing concepts with problematic content.

Well-known formalisms define a lot of relationships of different nature on concepts. Unlike them, here there is another formalism - a conceptual structure that is defined by a set of concepts with four kinds of mappings, the only purpose of which is to show ways of concept formation, ways of abstracting.

Definition 1. A conceptual framework $S=(N, T$, $G, C, A)$ is a finite set of concepts $N$ with four finite sets of mappings in the form $N \rightarrow N$ : type checking $T$, generalization $G$, aggregation $C$ and association $A$ [13].

A conceptual structure is designed to reflect the results of conceptual analysis of the subject domain in a formalized form, and expresses displaying some concepts into others. The abstractions used here are considered as mental operations that are necessary and sufficient for the mental isolation and transformation into separate concepts of representations that are accumulated relative to a formalized domain.

The concept scheme. The definition of the concept assumes that each concept has a schema, which is a set of features or simple concepts to define this concept. However, when defining a conceptual structure, only displaying some concepts into others is to be defined. The problem arises of defining schemata of concepts.

A scheme can be found for any concept from the conceptual structure $\mathrm{S}$ according to the following recurrent procedure:

- a scheme of a single concept is empty;

- a scheme of a simple concept consists of the name of this concept;
- a scheme of a differentiation concept is equal to the marked intersection of schemes of differentiated concepts;

- a scheme of an integration concept is equal to the marked integration of schemes of integrated concepts;

- a scheme of the concept obtained after integration and differentiation is equal to the marked unification of schemes of integrated concepts belonging to the marked intersection of schemes of differentiable concepts.

It should be noted that the ability to define schemes of abstract concepts allows displaying them as certain concepts as a list of entities that are defined through primary notions of the subject domain.

To verify a conceptual structure, it is required to check the computability of the schemes of all its concepts. The requirement of computability of concept schemes is the extension of a set regularity property to concepts. In this case, the computability of concept schemes guarantees the absence of concept definitions through themselves, which is inadmissible in any formal or substantial theory that claims to be adequate.

Thus, a conceptual analysis of the subject domain provides its ontological description given by a conceptual structure. The principal differences of the conceptual structure from other conceptual schemes are the following:

- terms are not divided into meanings, signs, concepts, connections and roles; instead, there is one term - a concept with particular manifestations such are meanings, signs, concepts, connections and roles;

- the possibility of representing associations as independent concepts, which allows, for example, expressing the generalization of associative links;

- the definition of concepts that can be both generalization and the association of other concepts;

- semantic description invariance, which does not require subject knowledge for its interpretation.

A conceptual structure of a subject area assumes assigning concepts and their abstraction methods. A concept scheme can be also computed. It is a set of simple concepts (attribute concepts) that allows considering abstract concepts as specific ones. However, it is unclear what sets of meanings of simple concepts determine one or another essence of concrete and abstract concepts. There is a concept intension to determine specific sets of simple concept meanings that define a particular essence of specific and abstract concepts. It sets the rules for correlating the sets of simple concept meanings with a particular entity from the extensional of the concept described.

\section{A conceptual model and communication}

Definition 2. A conceptual model $M$ of the subject domain is its conceptual structure $S$ that is supple- 
mented by a description of intensionals $D$ of all concepts in it, $M=(S, D)[14]$.

The Definition 1 says that the universal form of assigning an intention is enumeration of attribute sets of each entity belonging to the concept. In practice, it causes difficulties when the scope of the concept is sufficiently large. Another form of describing intensions is also possible - the use of procedures (formulas, functions) that resolve the extensionality of the defined concept.

When using databases, the low-level representation of the conceptual model of the subject domain can only be solved by means built into the database management system. So, single concepts are defined by the values of simple data types: integers, floating-point numbers, dates, symbols, fixed and variable-length lines, binary data.

To set simple concepts (attribute concepts), we might use integrity constraints that narrow the ranges of simple data values, or special tables containing valid values of a simple concept. Specific concepts are represented by tables with columns corresponding to simple concepts from its scheme.

The situation with abstract concepts is more complicated. Representation of an abstract type concept is also complicated by using a query to a database that processes records from several tables with the same set of fields simultaneously. The implementation of an abstract generalization concept requires a separate table with intensions of entities that are absent in the extensions of generalized concepts. Therefore, that the abstract generalization is represented by a query to the database, in which all records from the generalization concept table and unique entries from tables of generalized concepts with a set of fields belonging to the generalization concept scheme are a subject to processing.

Aggregation of concepts is represented by a query that executes the product of two or more tables. However, the implementation of the abstract association concept cannot be reduced to a query to a database and requires allocating a separate table that connects records from two or more associated concept tables.

Therefore, when using database management systems, the main tool for describing concept intensionals is the enumeration of sets of interrelated characteristics in the form of a physical or virtual table. A physical table is stored in memory. A virtual table is generated dynamically due to executing a query to a database. In this case, a table row (record) corresponds to the described entity from a concept extension, and the column (field) corresponds to a concept sign.

The use of a conceptual structure that specified in the form of a tree, as well as mapping of entities from concept extensionals in the form of lists are sufficient in the context of functioning of an information system designed to automate decisions of a specified class of applied problems.
If we abstract from a specific content of actions and procedures in the algorithms for solving applied problems, we can conclude that all such actions might be reduced to three abstract operations on concepts: concept creation, change and removal. Thus, a description that consists of three elementary operations is a semantically invariant form of describing a solution of applied problems in a modeled subject domain [15].

Concept creation. The operation of concept creation arises when a conceptual model of a subject domain is complicated. It includes determining a name of a new concept and setting a method for its abstraction. Calculation of a new concept schema follows automatically after its creation. Depending on the concept type, either a table (for simple and specific concepts, as well as for abstract generalization concepts and association concepts) or a representation/query (for abstract typing concepts and aggregation concepts) that can enumerate entities belonging to a created concept is created in a database.

Removing concepts. The operation of removing a concept arises in the case of changing visions of a subject domain. It consists in changing a description of all concepts in definitions of which include it.

Concept change. The operation of concept change is used when it necessary to fill concepts with a specific subject content. Change operations affect specific and simple concepts. In this case, three actions are possible: editing an existing entity (record), deleting an existing entity (record), and adding a new entity (record). The same actions are also performed on abstract generalization concepts and association concepts that have their own tables.

To implement the operations of creating, deleting and changing concepts in a database management system, there might be special stored procedures that ensure integrity and consistency of a conceptual model of a subject domain.

\section{Knowledge base}

The basis of any information system for processing knowledge is a formal apparatus for knowledge representation and manipulation in order to imitate a person's reasoning to solve the applied tasks. In turn, a knowledge base is a database containing facts about a certain subject area, as well as inference rules that allow automatic performing of inferences and getting new statements about existing or newly entered facts $[3,12]$.

An information system with a conceptual model of the domain $M=(S, D)$ can be considered as a knowledge base. In this case, the conceptual structure $S$ (concepts and abstraction methods) defines the rules for the derivation of knowledge, and the concepts intensions $D$ defines facts (judgments) on the subject area.

Judgements. Facts (judgments) are statements about the fact that the entities of the subject area are 
extensions of concepts. According to the formula (1), the essence $E$ belongs to the extension of the concept $N$ if and only if the set of values of $E$ essence attributes, which is ordered according to the scheme of the concept $\operatorname{shm} N$, belongs to the intension of the concept int $N$ :

$$
\left(\bigsqcup_{\forall P_{i} \in \text { shm } N} P_{i}[N]\right) \in \operatorname{int} N \leftrightarrow N(E), \quad \text { where } \quad \text { is }
$$

marked up (ordered) merge performed with repeating elements; $P_{i}[E]$ is a functor that returns the value of the concept-attribute $P i$ of an entity $E ; \leftrightarrow$ is two-way logical connective; $N(E)$ is single predicate of the essence $E$ belonging to the extension of a concept $N$, $N(E) \leftrightarrow E \in \operatorname{ext} N$.

According to the formula (1) feasibility of a single predicate $N(E)$ is determined by the current state of intentions $D$, i.e. an information system implements an open world model.

Inferences. We might define any reasoning as a transition from one or more judgments that are a premise of an inference to a statement that is the consequence of an inference. Rules for constructing inferences are based on the inference rules generally valid in a subject domain, i.e. generating true statements under all possible assumptions.

The rules for constructing inferences in the case under consideration are based on inference rules that are formalized in the conceptual structure of the subject domain. The conceptual structure itself is considered as a formal theory that preserves the truth of all consequences in it.

The following logical statements that specify knowledge inference rules:

$$
\begin{aligned}
& \underset{\left(\forall N_{i}>N\right.}{\vee} N_{i}(E) \rightarrow N(E) \underset{\left(\forall N_{i} \triangleright N\right.}{\vee} N_{i}(E) \leftrightarrow N(E) \\
& N(E) \rightarrow \underset{\left(\forall N_{i} \succ N\right.}{\wedge} N_{i}(E) N(E) \leftrightarrow \underset{\left(\forall N_{i} \mid \succ N\right.}{\wedge} N_{i}(E),
\end{aligned}
$$

where $\vee(\wedge)$ is a logic connective OR (AND); $>(\succ, \triangleright, \mid \succ)$ is a mapping generalization sign (association, typing, aggregation) of concepts; $\forall$ is a generality quantifier; $\rightarrow$ is a logic connective of following [12].

The inverse proposition of the first inference rule from (2) is true only for the abstraction of specification typing (second rule), since (3) says that the specialization generalization abstraction describes a larger number of entities than in the union of extensions of generalized concepts.

In turn, the inverse proposition of the inference first rule from (3) is true only for the abstraction of decomposition aggregation (second rule), since (2) says that the abstraction of the individualization association describes a smaller number of entities than in the Cartesian product of associated concepts extensions.

Queries. To turn an information system into a complete knowledge base, it is necessary to implement que- ries for extracting facts (assertions) and outputting meaningful statements about the modeled domain.

Facts (assertions) and statements are propositions with logical connectives AND, OR, NOT with two types of predicates:

- one-place membership predicates of the entity $E$ to the concept $N$ of the type $N(E)$;

- relations $P[E]^{\circ} V$, where $P[E]$ is a functor that returns the value of the attribute concept $P$ of the entity $E$, $\circ$ is a relation $\operatorname{sign}(=, \neq,>, \geq,<, \leq,>$ etc. $), V$ is some value concept.

After setting restrictions on one or more characteristic values, the information system searches for entities that satisfy the specified conditions and then displays them as child nodes of the search node.

The search for concept essences by the key is performed in a similar way after entering the key or its part in the name of the search node. If the key has several signs, then they are separated by a special sign.

A more complex search requires using queries to the knowledge base. There is a corresponding query language and a knowledge output machine supporting it, which implements inference rules (1), (2) and (3). However, for many application problems it is sufficient to use a client application subject line to find concepts in their conceptual structure by their names with the subsequent search for the required entities in the extensions of the found concepts.

\section{A knowledge representation form}

In addition to knowledge presentation, extraction and actualization, another important task must be solved - knowledge representation. It consists in changing the form of knowledge presentation. It is based on construction of conceptual submodels with their subsequent visualization by special programs.

Definition 3. A submodel $M^{\prime}$ 'of the concept model $M=(S, D)$ is a conceptual model $M^{\prime}=\left(S^{\prime}, D^{\prime}\right)$ with the following relations: $S^{\prime} \subseteq S, D^{\prime} \subseteq D$, where $S^{\prime}$ is some substructure (fragment) of the concept structure $S, D^{\prime}$ is a description of concept intensionals in the conceptual structure $S^{\prime}$.

A conceptual submodel is constructed according to the following procedure [16]. First, a number of basic concepts is identified, which must be included in the submodel according to the conditions of the problem being solved. Then the conceptual substructure is iteratively constructed. It includes all concepts having connections with the initial and then with the current set of them. Iterations finish when a current set of concepts ceases to replenish itself. At the end of the procedure, a description of intensionals of the concepts from the conceptual substructure is created.

The construction of conceptual submodels is necessary to create data that is required for visualizing subject domain fragments by third-party programs. To display such submodel, the forms implemented by the corresponding application programs might be used: Gantt 
charts, resource lists, resource scheduling, figures, slides, videos, etc. For this purpose, an information system includes a module which performs their visualization based on their conceptual models.

Submodels might be also used to automatically create various kinds of documents (files). In this case, the submodel has expression rules (representation) of concepts in a document body. The expressive means for such representation will depend on the required display form (text, graphics, sound, animation, etc.).

To display a submodel in text form, representation rules might be made in the form of a document template. Template creation involves using a special markup language that allows specifying the forms of concept expression in the text.

The extraction operator allows retrieving and inserting into its location a formatted value retrieved from the conceptual model according to the specified path. The calculation operator is used to represent a formatted value of some calculated expression in the text form. The syntax and semantics of expressions are like those of high-level languages. In the implemented information system, interpretive languages such as VBScript and JScript might be used as languages for specifying expressions.

The setup operator serves to change values in a conceptual model and additionally might be used to create temporary simple concepts (variables). The selection operator is necessary for implementation of text branching in the model representation process. The iteration operator represents composite concepts. Operators can be interleaved, since all their parts are a plain text.

Submodels of other stable fragments of subject domains and their corresponding visualization forms have a similar way of creation. For example, charts and diagrams; infographic (graphical representation of charts, maps, figures, formulas, etc.); technical graphics (graphical representation of schemes, drawings, axonometry); dynamic business process models in various notations (graphical representation of processes and their current states).

\section{Software implementation of the proposed approach}

The obtained solutions were tested on voice control for information systems. The solutions of one of the most popular programs for voice control of actions on a computer (Typle) were used as analogues due to simple creating a voice command control script in it. Its limitations are related to the command duration no more than one and a half seconds and the number of commands used -15 .

In addition, the authors used the voice control solutions in Yandex, in particular, solutions on voice message digitizing.
Implementation of the proposed approach structurally involves:

- building an anthological knowledge base;

- building a base of modes of actions for a subject area;

- development of voice recognition tools (using existing ones);

- a query generation subsystem based on voice recognition system output;

- a program call generation subsystem when these programs have the required capability to execute a query;

- visual representation of a demand, its execution and confirmation of execution.

The developed solutions are experimentally tested on a mockup sample.

\section{References}

1. Vinogradov G.P. Intelligent agent's decision-making. Software \& Systems. 2010, no. 3, pp. 45-51 (in Russ.).

2. Ashikhmin I.V. Analysis of decision makers' preferences by partial descriptions of multi-criteria objects. Proc. of ISA RAS. 2005, vol. 12, pp. 7-15 (in Russ.).

3. Pytyev Yu.P. Opportunity. Elements of Theory and Application. Moscow, Editorial URSS Publ., 2000, 192 p.

4. Altunin A.E., Semukhin M.V. Decision-Making Models and Algorithms under Fuzzy Conditions. HTML Course. Tyumen, 2000, $352 \mathrm{p}$.

5. Podinovsky V.V. Introduction to the Theory of Criteria Importance of in Multi-Criteria Decision-Making Tasks. Moscow, Fizmatlit Publ, 2007, $64 \mathrm{p}$.

6. Vinogradov G.P., Ganichev A.V., Koshkina G.V. Decision making with selectable representation structure under uncertainty. Information and Mathematical Technologies in Science and Management. 2017, no. 2, pp. 88-94 (in Russ.).

7. Bogdanova A.V., Nogin V.D. Narrowing the Pareto set based on the simplest sets of fuzzy information about the relative importance of criteria. Vestnik of St. Petersburg Univ. Applied mathematics. Computer Science. Control Processes. 2007, iss. 1, pp. 3-17 (in Russ.).

8. Attetkov A.V., Galkin S.V., Zarubin V.S. Optimization Methods. Moscow, BMSTU Publ., 2003, 440 p.

9. Nogin V.D. Multi-Criteria Decision Making. St. Petersburg, Yutas Publ., 2007, 104 p.

10. Vinogradov G.P., Vinogradova N.G. Decision making with a selectable preference structure. Proc. of Irkutsk State Tech. Univ. 2016, no. 10 , pp. 90-101 (in Russ.). DOI: 10.21285/1814-35202016-10-90-101.

11. Rao A.S., Georgeff M.P. BDI agents: from theory to practice. Proc. ICMAS, 95. San Francisco, CA, 1995, pp. 312-319.

12. Vykhovanets V.S. Applied conceptual analysis. Proc. 8th Int. Conf. "Cognitive Analysis and Management of Situation Development”. Moscow, Institute of Control Sciences Proc., 2009, pp. 62-65 (in Russ.)

13. Vykhovanets V.S., Yatsutko A. Dynamic business process management based on the combined control and data networks. Preprints of the 2013 IFAC Conf. on Manufacturing Modelling, Management, and Control. St. Petersburg State Univ. Publ., 2013, pp. 672-677 (in Russ.).

14. Koganovsky M.Z., Kalinichenko L.A. Conceptual and ontological modeling in information systems. Programming and Computer Software. 2009, vol. 35, no. 5, pp. 3-25 (in Russ.)

15. Gorsky D.P. Issues of Abstraction and Education Concepts. Moscow, AN SSSR Publ., 1961, 352 p.

16. Layout, Design and Implementation of Interactive Information Systems. E.I. Lomako (Ed.). Moscow, Finansy i statistika Publ., 1993, 320 p. 


\section{Онтологии в задачах построения понятийной модели предметной области}

Г.П. Виноградов ${ }^{1}$, д.m.н., npoфeccop,wgp272ng@mail.ru

A.A. Прохоров ${ }^{2}$, зав. отделением, forworkap@mail.ru

${ }^{1}$ Тверской государственный технический университет, г. Тверь, 170026, Россия

${ }^{2}$ НИИ «Центрпрограмлсистем», г. Тверь, 170024, Россия

Предметом исследований являются коммуникации информационных систем между собой и информационных систем с оператором. Актуальность данной проблемы обусловлена интеллектуализацией информационных технологий, в результате которой информационная система приобретает черты интеллектуального агента. Это открывает новые перспективы для направления, называемого цифровой экономикой, где важную роль играет информационное взаимодействие на сетевом уровне.

Методическую базу исследований составили полученные в теоретической семиотике результаты использования онтологии как формы представления знаний о реальном мире, а также публикации отечественных и зарубежных ученых по проблеме коммуникации между информационными системами.

В процессе исследований выполнен анализ процесса коммуникации. Выявлено, что интеллектуальный агент рассматривает сообщение как результат принятия решения либо для информирования, либо для изменения состояния другого агента. Показано, что коммуникацию следует рассматривать как один из видов управления, например поведением.

Доказано, что применительно к теории поведения этот подход потребовал включения в предметную область теории выбора психологических аспектов. Это прежде всего проблемы восприятия, осознания, понимания свойств ситуации выбора и построения оценок результатов выбора, общения, конфликта, введения новых понятий и отношений между ними ряда других. Системы поддержки процесса коммуникации должны содержать модель предметной области, понятной и интерпретируемой пользователем. Показано, что наиболее подходящим способом ее построения является понятийное моделирование предметной области на основе онтологий. Понятийная модель состоит из понятийной структуры и описания содержания понятий. Понятийная структура определена как множество понятий, на которых заданы четыре отображения абстрагирования: обобщение, типизация, ассоциация и агрегация. Описание содержания понятий осуществляется с помощью таблиц БД. Существенным отличием используемой понятийной модели от других является описание ассоциации как обычного понятия. Показано, что благодаря семантической инвариантности области понятийной интерпретации удается улучшить технологические и эксплуатационные характеристики информационной системы.

Предлагаемый подход создает основу для разработки и организации интерфейса искусственных сущностей как между собой, так и с оператором на основе некоего «профессионального языка», релевантного некоей предметной области, что предполагает рассмотрение интерфейса как знаковой системы и использование для ее построения методов и подходов теории искусственного интеллекта.

Ключевые слова: принятие решений, целеустремленные системы, нечеткое суждение, ситуация выбора

\section{Литература}

1. Виноградов Г.П. Моделирование принятия решений интеллектуальным агентом // Программные продукты и системы. 2010. № 3. С. 45-51.

2. Ашихмин И.В. Анализ предпочтений ЛПР на частичных описаниях многокритериальных объектов // Тр. ИСА РАН. 2005. T. 12. C. 7-15.

3. Пытьев Ю.П. Возможность. Элементы теории и применения. М.: Эдиториал УРСС, 2000. 192 с.

4. Алтунин A.Е., Семухин M.В. Модели и алгоритмы принятия решений в нечетких условиях. HTML-курс. Тюмень: Изд-во ТГУ, 2000. 352 с.

5. Подиновский В.В. Введение в теорию важности критериев в многокритериальных задачах принятия решений. М.: Физматлит, 2007. 64 с.

6. Виноградов Г.П., Ганичев А.В., Кошкина Г.В. Принятие решений с выбираемой структурой представлений в условиях неопределенности // Информационные и математические технологии в науке и управлении. 2017. № 2. С. 88-94.

7. Богданова А.В., Ногин В.Д. Сужение множества Парето на основе простейших наборов нечеткой информации об относительной важности критериев // Вестн. СПб ун-та: Прикладная математика. Информатика. Процессы управления. 2007. С. 3-17.

8. Аттетков А.В., Галкин С.В., Зарубин В.С. Методы оптимизации. М.: Изд-во МГТУ им. Н.Э. Баумана, 2003. 440 с.

9. Ногин В.Д. Принятие решений при многих критериях. СПб: Ютас, 2007. 104 с.

10. Виноградов Г.П., Виноградова Н.Г. Принятие решений с выбираемой структурой предпочтений // Вестн. Иркутского гос. технич. ун-та. 2016. Т. 20. № 10. С. 90-101. DOI: 10.21285/1814-3520-2016-10-90-101.

11. Rao A.S. and Georgeff M.P. BDI agents: from theory to practice. Proc. ICMAS-95, San Francisco, CA, 1995, pp. 312-319.

12. Выхованец В.С. Прикладной понятийный анализ // Когнитивный анализ и управление развитием ситуаций: тр. VIII Междунар. конф. М.: Изд-во ИПУ РАН, 2009. С. 62-65.

13. Vykhovanets V.S., Yatsutko A. Dynamic business process management based on the combined control and data networks. Pre-prints of the 2013 IFAC Conf. on Manufacturing Modelling, Management, and Control. St. Petersburg State Univ. Publ., 2013, pp. 672-677.

14. Когановский М.З., Калиниченко Л.А. Концептуальное и онтологическое моделирование в информационных системах // Программирование. 2009. Т. 35. № 5. С. 3-25.

15. Горский Д.П. Вопросы абстракции и образования понятий. М.: Изд-во АН СССР, 1961. 352 с.

16. Макетирование, проектирование и реализация диалоговых информационных систем; [под ред. Е.И. Ломако]. М.: Финансы и статистика, 1993. 320 с. 